\title{
Ç1. Aleksandr Samoylovich: Türk dillerin sınıflandırılması: Bazı eklemeler ${ }^{1}$
}

\section{Mariana BUDU2}

\begin{abstract}
$\ddot{\mathbf{O} z}$
Bu makale Aleksandr Samoylovich'in 1922 yllında Sankt-Peterburg'da Yaşayan Doğu Dilleri Fakültesi dergisinde yayımladığı "Некоторые дополнения к классификации турецких языков" (s.1-14) adlı makalesinin Türkçeye çevirisidir. Aleksandr Samoylovich’in Türk dillerin sınıflandırılması: Bazı eklemeler makalesinin başka tercümeler de bulunmaktadır.
\end{abstract}

F. E. Korş3’un "Bir dilin birden fazla sınıflandırması varsa, hiç biri bir işe yaramayacaktır." sözü doğru kabul edilirse, kendisine ait sınıflandırmasını da o hâlde çöpe atmamız gerekecektir. Bundan dolayı, Korş’un bu sözüne itibar edilmemesi gerektiği düşüncesindeyiz. Korş’un "Türk boylarının, yani Türk dillerin sınıflandırılması" çalışması, içinde bulunduğumuz zamanın son çalışması olarak kabul edilmektedir. Fakat onu tam boyutlu bir çalışma olarak kabul etmek de doğru değildir. Çünkü Türk dillerinin sınıflandırılmasını oluşturmak için gerekli şartlara tam olarak sahip değiliz. Hatta 60 yıl önce N. İ. İlminskiy'nin ${ }^{4}$ de belirtiği gibi, Türk dillerinin sınıflandırılmasının bu kadar kolay olmasını, mantığım kabul etmezdi.

Türk dillerini sınıflandırma denemeleri, genellikle başarı ile sonuçlanmaktadır. Fakat burada belirtmemiz gereken önemli bir nokta vardır ki Türk dillerinin tarihi gelişimi oluşturulmadan, başarıı bir sinıflandırmadan bahsetmek mümkün değildir. Ayrıca Alman asıllı Rus Türkolog V. V. Radloff un içinde bulunduğumuz zamanın güncel ve düzeltilmiş çalışmasını da burada zikretmemiz gerekmektedir. 5

Radloff ve Korş'un hâlihazırda Türk dillerinin sınıflandırılması ${ }^{6}$ çalışmalarının olması, yeni bir sınıflandırma yapılmasını gerektirmemektedir. Ancak, Türk dillerinin üzerine yapılan yeni çalışmalar ve yeni bilgiler ortaya çıtıkça Radloff ve Korş'un sınıflandırmalarındaki eksiklikler veya yanlışları gidermek için yeni güncellemelerin yapılması zorunlu hale gelmektedir. Bu, sadece bir temenni değil, aynı zamanda gerekliliktir.

$1 \quad \mathrm{Bu}$ makalenin özeti, Rusya Bilimler Akademisi Antropoloji ve Etnografya Müzesinde Radloff anısına düzenlenen seminerde sunulmuştu.

2 Dr. Öğr. Gör., İstanbul Üniversitesi, Slav Dilleri ve Edebiyatları, Leh Dili ve Edebiyatı (İstanbul, Türkiye), mariana.budu@istanbul.edu.tr, ORCID ID: oooo-0001-9000-4029 [Çeviri, Makale kayıt tarihi: 21.05.2021-kabul tarihi: 20.06.2021; DOI: 10.29000/rumelide.xxxx]

3 F. E. Korş, "Türk Boylarının Dillerinin Sınıflandırılması”, Etnografya Dergisi, Moskova 1910, s. 84-85. Sonradan, Korş tarafından bu sınıflandırmada bazı düzeltmeler yapılmıştır, fakat güncel hâliyle hiç yayımlanmamıştır.

N. İ. İlminskiy, Türk-Tatar Diline Giriş, Kazan 1862, s. 21.

V. V. Radloff, Phonetik der Nördlichen Türksprachen, Leipzig 1882, s. 280-291.

Ayrica bkz., A. Vambery, Das Türkenvolk, Leipzig 1885, s. 85-86; L. Kaan, Introduction a l'histoire de l'Asie, Paris 1896, s. 34-35; N. F. Katanov, "Kazan Üniversitesinde Bulunan El Yazmaları", 1894; ve eski sınıflandırmaları kullanan İ. N. Berezin, Recherches sur les Dialectes Musulmans. I. Systeme des Dialectes Turcs, Kazan 1848. Bununla birlikte bkz., N. A. Aristov, "Türk Boyların Etnik Yapıları Üzerine Bazı Notlar", Jivaya Starina Dergisi, 1896, 3(4), s. 445-456; V. V. Bartold'un Batı-Doğu bölümündeki incelemelerine bkz., C. XI, s. 341.

Adres $\mid$ Address

RumeliDE Dil ve Edebiyat Araşttrmalar Dergisi $\quad$ RumeliDE Journal of Language and Literature Studies Osmanağa Mahallesi, Mürver Çiçeği Sokak, No:14/8 $\quad$ Osmanağa Mahallesi, Mürver Çiçeği Sokak, No:14/8

Kadıköy - İSTANBUL / TÜRKIYE 34714 Kadıköy - ISTANBUL / TURKEY 34714 e-posta: editor@rumelide.com

e-mail: editor@rumelide.com

tel: +90 505 7958124, +90 2167730616 phone: +90 505 7958124, +902167730616 
Rahmetli N. F. Katanov'un birden çok örnek içeren değerli doktora çalışması, Radloff'un Yakut dili üzerine yaptığı çalışmaları gibi çalışmalar ve buna benzer araştırmalar7, bu konu üzerine yapılan incelemeleri kolaylaştırmaktadır.

Türk dilleri üzerine yapılan bazı çalışmaların değeri -büyük bir önem taşımasa da- sınıflandırmalarda kullanılan terminoloji karışıklığına yol açmamak için onların da gözden geçirilmesi gerekmektedir.

Dil aileleri ve şiveleri sınıflandırılırken bazen güney, kuzey gibi terimlerin kullanıldığı görülmektedir. Fakat bu gibi terimlerin kullanılması, önemli sıkıntıların ortaya çıkmasına yol açmaktadır. Bununla beraber bu veya şu sebepten dolayı, dil ailelerinin "tarih öncesi” dönemleri incelenmeden, eski, orta ve yeni gibi kullanılan dil terimleri de kabul edilmemelidir.

Türk dilleri ve şivelerini sınıflandırırken, Türk halklarının oluşumunda ve yerleşiminde devrim yaratan halklara göre tarihi katmanları adlandırmak mümkündür: Hunlar öncesi dönem, Moğollar öncesi veya sonrası dönem gibi. Türk dillerinin ve şivelerinin gruplandırılmaları ise diğer dillerde yapıldığı gibi, eğer durumlar buna müsaade ediyorsa, dil özelliklerine göre sınıflandırabilir. Örneğin, gruplara göre Türkmen grubu, ol- grubu, Güneybatı grubu şeklinde ayrılabilir. Tam veya bitmiş bir sinıflandırma ve gruplandırma çalışması, ancak bu şekilde mantıklı ve doğru elde edilebilir gibi görünmektedir.

Bu çalışmadaki amaç, Türk dilleri üzerine yeni bir sınıflandırma yapmak değil, var olan çalışmaların eksiklerini gidermek ve onlara ilavelerde bulunmaktır.

III

Korş, Türk dillerini sınıflandırırken, konuyu fonetik ve morfolojik unsurlar bakımından incelemiştir. Böylece, üç grup elde etmiştir:

\section{Kuzey Grubu:}

1. “g” ünsüzünün kelime sonunda "y” ünsüzü ile karşılanması: tag = tay “dağ”.

2. Şimdiki zaman eki "a" ünlüsünün, "tur-" yardımcı fiili ile birlikte ifade edilmesi geleturur-men "geliyorum".

\section{Doğu Grubu:}

1. Kelime sonunda "g” ünsüzünün korunması,

2. Şimdiki zaman kipinin "-r" ile ifade edilmesi kelür men "geliyorum".

\section{Batı Grubu:}

1. “g” ünsüzünün ünsüzden sonra düşmesi kalgan = kalan gibi,

2. S Şimdiki zaman kipinin doğu grubunda olduğu gibi “-r” eki ile ifade edilmesidir.

Korş’un sınıflandırmasında bu üç grup dışında, karmaşık grubu altında bir dördüncü grup mevcuttur. Bu grup da iki bölüm altında incelenmiştir.

7 N. F. Katanov, Opıt İssledovaniya Uryanhayskago Yazıka s Ukazaniyem Glavneyşih Rodstvennı Otnoşeniy ego $k$ Drugim Yazıkam Tyurskago Kornya, Kazan 1903; V. V. Radloff, "Die Jakutische Sprache in ihrem Verhaltnisse zu den Türksprachen”, L'Academie Imperiale des Sciences de St. Petersburg, T. VIII, No: 7, St. Petersburg 1908; K. Foy, "Azerbaiganische Studien mit einer Charakteristik des Südtürkishen”, Mittheilungen Berlinskoy Seminariy Vastoçnih Yazıkov, T. VI, (2), 1903.

Adres
RumeliDE Dil ve Edebiyat Araşttrmaları Dergisi Osmanağa Mahallesi, Mürver Ciçeği Sokak, No:14/8 Kadıköy - İSTANBUL / TÜRKIYE 34714 e-posta: editor@rumelide.com tel: +90 $5057958124,+902167730616$
Address

RumeliDE Journal of Language and Literature Studies

Osmanağa Mahallesi, Mürver Çiçeği Sokak, No:14/8

Kadıköy - ISTANBUL / TURKEY 34714

e-mail: editor@rumelide.com,

phone: +90 505 7958124, +90 2167730616 
Sinıflandırmanın yöntemi, ilkeleri ve verilen örnekler farklı olmasına rağmen Korş’un Batı grubu ve Radloff'un Güney grubu birbiriyle tamamen örtüşmektedir. Bu grup, yeniden nasıl adlandırılırsa adlandırılsın, içerik değişmeyecektir ve gelecekte yapılacak çalışmalar sadece bazı ayrıntılarla zenginleşecektir. Bu grupta Türkmen, Azerî, Osmanlı (Eski Anadolu Türkçesi, Suriye, Balkan yarımadası), Gagavuzca ve Güney Kırım yer alır. Bizce, bu grubun en belirgin özelliği "ol-“ fiilidir. Diğer gruplarda "ol-“ fiili "bol-, pol-, pul-“ şeklindedir. Grubun bir başka özelliği ise, Korş’un da dediği gibi, ünsüzden sonra "g” ünsüzünün düşmesidir, kalgan = kalan gibi. (Bu özellik daha sonra belirteceğimiz gibi Bulgar dilinde de mevcuttur). Söz konusu grubun dillerin ve diyalektlerin temeli, 11. yüzyılda Selçuklu döneminde, Aral ve Hazar bozkırlardan İran ve Küçük Asya’ya yayılan OğuzTürkmen (guzzı, uzı) tarafından konuşulan Eski Oğuz-Türkmen dillerine ve şivelerine dayanmaktadır.

Bu grupta yer alan bazı diller, bazı durumlarda diğer grupların dil özelliklerini de içermektedir. Dolayısıyla, Trans-Hazar Türkmenlerinin diyalektleri genel olarak bu gruba aittir, fakat ol-/bolözelliğinden dolayı diğer gruplara da temas etmektedir. Kanglı-Kıpçak dilinin eski bir karışımı olması ihtimal dâhilindedir.

Dilin özeliğinden dolayı, bu grubu ol- grubu şeklinde adlandırmak daha doğru olacaktır. Radloff ve Korş tarafından bu şekilde adlandırılan bu grubun adlandırılmasını korumak kaydıyla ve günümüzde Güneybatı bölgesinde ol- grubu'nu konuşan halkların bulunmasından dolayı tarafımızdan Güney grubu tabiri eklenmekte ve ayrıca Türkmence ${ }^{8}$ kökenli dil olduğu tarafımızdan belirtilmektedir.

Güneybatı grubu dilini konuşan Türk boylarının coğrafi yerleşim dağılımı şu şekildedir: Harezm (Hive) Cumhuriyeti, Buhara Cumhuriyeti, Afganistan, Türkistan bölgesi, Türkmenler (eski adı TransHazar) bölgesi, Azerbaycan nüfusunun bir bölümü, Astrabad, Horasan ve Tersia'nın bazı bölgeleri, Ermenistan, Gürcistan Cumhuriyeti, Anadolu, Suriye'nin kuzeyi, Balkan yarımadası ve İstanbul, Besarabya, Kırım’ın güney sahili, Kumsek, Kuzey Kafkasya bozkırları, Astrahan dağları (burada da Türkmenler).

\section{$\mathrm{V}$}

Korş’un Kuzey grubu, Doğu grubu ve Karmaşık grup olarak adlandırdığı 4. grup ile Radloff'un diğer üç grubu (Doğu, Batı, Orta Asya) örtüşmektedir. Fakat Radloff sonradan kendi sınıflandırmasında her ne kadar bazı değişiklikler yaptıysa da yine de her iki sınıflandırmanın bazı kısımlarında ciddi değişikliklerin yapılmasına ihtiyaç duyulmaktadır. Genel olarak, Radloff un sınıflandırması kendisini kanıtlar görünmekle birlikte Korş’un sınıflandırması delil ve örnek eksikliğinden dolayı yetersizdir.

Korş’un Doğu grubu, Orhun (Yenisey yazitları), Uygur, Çağatay ve Kuman ölü dilleri ve Karagas, tartışmalarla Koybal, Sagay ve Salar modern dillerini içermektedir. Korş'un bu grupta yer verdiği diller, Radloff un değişiklik yapmadan önceki tasnifinde (Salar dışında) hemen her grupta yer alırdı, Güney grubu'nda Orhun (Yenisey yazıtları), Doğu grubu'nda Uygur, Karagas, Kaybal, Sagay, Orta Asya grubu'nda Çağatay ve Batı grubu'nda Kuman dilleridir. Radloff un yayımlama firsatı bulamadığı ancak el yazması olarak elimizde bulunan tasnifinde Moğol öncesi döneme ait, Doğu Türk dillerini

8 N. Berezin, Recherches sur les Dialectes Musulmans. I. Systeme des Dialectes Turcs, çalışmasında "Türkçe" adlandırmasını teklif etmiştir, bkz. s. 27; V. V. Radloff, Phonetik der Nördlichen Türksprachen, çalışmasında ise "Selçuklu" adlandırmasını teklif etmiştir.

RumeliDE Dilve Edebiyat Adres Address

Osmanağa Mahallesi, Mürver Çiçeği Sokak, No:14/8 Osmanağa Mahallesi, Mürver Çiçeği Sokak, No:14/8

Kadıköy - İSTANBUL / TÜRKIYE 34714 Kadıköy - ISTANBUL / TURKEY 34714

e-posta: editor@rumelide.com

tel: +90 $5057958124,+90216773$ o 616 phone: +90 505 7958124, +90 216773 o 616 
Orhun (Yenisey yazıtları) ve Uygurca olarak iki grupta incelemiştir: Kuzeydoğu ve Güneydoğu grubu, ayrıca burada kelime başında $y=c ̧=s$ özellikleri taşıyan Kuzeybatı grubu'nu da eklemektedir.

Yenisey-Orhun yazıtlarının dili ile Uygur yazıtlarının dili arasında dil özellikleri bakımında yeterli derecede farklılıklar gösteren bulgular vermemektedir. Bundan dolayı biz de bu iki dili hemen ayırma eğiliminde değiliz, fakat bununla birlikte Yenisey-Orhun ve Uygur yazıtlarının dili arasındaki bazı farklılıkları da gözden kaçırmamalıyı. Diğer taraftan Radloff un ilk tasnifinde yer alan Moğol öncesi Türk dillerinin sınıflandırması bölümü Radloff'un el yazması halinde kalan sınıflandırmasından daha karmaşıktır. Özellikle "Selçuklu şiirleri” yazılmadan önceki Oğuz dilinin izleri, modern Güneybatı (Radloff'ta güney, Korş’ta batı) dillerinde9 rastlanmaktadır. Fakat hiç bir şekilde doğrudan doğruya izlenemezler. Bu diller hakkındaki iddialar bazı dil özelliklerine rağmen doğrudan Yenisey-Orhun yazıtlarına bağlanamazlar.

Türk halklarının tarihi gelişimi, göçleri, kendi aralarında ve diğer halklarla temasları, dillerini de etkilemiştir. Bundan dolayı hiç bir zaman sınıflandırmanın kolaylığından, kısalığından veya basitliğinden söz edilemez. Burada Türk dillerinin sınıflandırılması, özelliklerinden ve grupların çeşitliliğinden dolayı, geniş olması gerekliliğini kabul etmemiz gerekir. Yapılacak olan sınıflandırmanın orijinalliğinden ancak bu durumda bahsedebiliriz.

Böylece tarafımızca düzenlenen sınıflandırmanın doğal olarak genişleyeceği ve yönünün de belirgin hâle geleceği hususunda lüzumlu bir adım daha atarak Korş'un sınıflandırmasındaki fonetik özelliklere ilave olarak bir fonetik özellik de biz eklemekteyiz. Bu özellik, kelime ortasında ve sonunda $d>t, z>s$ ve $y$ değişimidir: adak>ayak>atak, azak>ayak, kod $>k o t, k o s>k o y$ gibi.

Sinıflandırmada, bu yeni fonetik özelliği ekleyerek önceden tarafımızca benimsenen Güneybatı grubu'nun istikrarını korumalıyız. Fakat Korş'un sınıflandırmasında yer alan Doğu grubu'nda birkaç değişiklik yapılmalı. Çünkü Güneybatı grubu, "y-yot” diyalektlerini içermektedir. Böylece Korş’un Doğu grubu'na $d, z, t$ diyalektlerini ekliyoruz. Ancak $y$ özelliklerini taşıyan ve aynı zamanda Radloff'un sınıflandırmasında da belirtildiği gibi Çağatay ve Kuman (ya da Kıpçak) dilleri diğer gruplara ait olmalarından dolayı bunları hâriç tutuyoruz.

Alt grup "d" diyalektleri: Tarafımızca hazırlanan ve Korş’un ${ }^{10}$ hazırladığı sınıflandırmada da olduğu gibi bazı dil özelliklerinden dolayı, ölü dillerden Yenisey-Orhun ve Uygur yazıtlarının dili, modern dillerinden Soyot ve Uranhay"1, (Korş’un çalışmasının önsözünde belirtilen, fakat çalışma içinde yer verilmeyen diller) Karakas ve Salar da yer almaktadır.

Alt grup "z" diyalektleri: Sarıg-Uygur (Korş tarafından belirlenmemiş), Kamasin, Koybal, Sagay, Kaç, Beltir, Şor, Kızıl, Kiyuritskiy² de yer almaktadır.

Alt grup " $t$ " diyalektleri: Burada Radloff'un sinıflandırmasında yer almayan Yakutçayı dâhil etmekteyiz. Fakat her ne kadar Korş "Yakutça, bazı özelliklerden dolayı, Karagas diline yakındır, ancak Yakutça, Altayca ve Çuvaşça ile hiç ortak özelliğe sahip değildir.” (bkz. s. 13); iddiasında bulunsa da yine de Yakutçayı Karmaşık grubu’nun alt gruplarında bulunan "b" maddesine yerleştirmişti. Böylece

9 Bkz. 11. yüzyılın yazarı Kâşgarlı Mahmud'un bir kaç sene önce İstanbul'da yayımlanan Dîvânü Lugâti’t Türk'te Güneybatı şivelerin izlerini taşıdığı görülmektedir: baran = bargan (C. I, s. 35); deve = teve (C. II, s. 154); ben = men (C. I, s. 284) gibi. W. Bang’’n Orhun-Yenisey yazıtları üzerine yaptığı yeni çalışması tarafimıza ulaşamamıştır.

Bilindiği gibi, “d” diyalektinin özeliğini taşıyan Uygurca el yazması metinler bulunmaktadır.

Bugün Güney Sibirya şivelerinde Tuva ağıları.

Bugün Güney Sibirya'daki şivelerden Hakas ağızları.

Adres $\mid$ Address

RumeliDE Dil ve Edebiyat Araşttrmaları Dergisi Osmanağa Mahallesi, Mürver Çiçeği Sokak, No:14/8 Kadıköy - ISTANBUL / TÜRKIYE 34714 e-posta: editor@rumelide.com

RumeliDE Journal of Language and Literature Studies Osmanağa Mahallesi, Mürver Çiçeği Sokak, No:14/8

Kadıköy - ISTANBUL / TURKEY 34714

e-mail: editor@rumelide.com,

tel: +90 505 7958124, +90 216773 o 616 phone: +90 505 7958124, +90 2167730616 
Korş'ta Yakut dili, Çuvaşça ile bu grubun içinde yan yana yer almaktadır. Bu nedenle Yakutça, Türk dilleri arasında en karışık ve özgün olan dillerden biridir. ${ }^{13}$ Radloff tarafından "nachtürkisch" olarak adlandırılan Yakut dili, Korş’un (gora-tıa) terminolojisine göre, genel özelliklerinden dolayı Doğu ve Kuzey grupların sinırında yer almaktadır.

Orhun Yazıtları ve Yakutça hariç tutulduğunda tarafımdan yenilenen Doğu grubu Radloff'un ilk baskısındaki sınıflandırması ile büyük ölçüde eşleşmektedir. Bizce, kendine özgü dil özelliklerinden dolayı bu grup, diğer gruplardan ayrı, kendi içinde alt grupları olan "d" diyalekti şeklinde de adlandırılabilir. Türk dünyasının doğu, daha doğrusu kuzeydoğu bölgelerinin eski ve yeni dillerini içine alan bu grup Kuzeydoğu grubu ([güneybatı karşısında] veya dil kökeninden dolayı Uygurca ${ }^{14}$ ) olarak adlandırabilir. Dilin "ol-/bol-“ özelliğinden dolayı Kuzeydoğu grubu "bol-“ diyalektine aittir.

$\mathrm{Bu}$ gruba ait ehemmiyetsiz sayıda Türk halkları esas olarak Sibirya'da (genellikle Lena ve Yenisey nehirlerinin yataklarında, kısmen Kuzey Altay dağlarının eteklerinde, Moğolistan'ın Uranhay bölgesi ve Batı Çin) ${ }^{15}$ yaşamaktadırlar.

Ne Korş tarafından yapılan sınıflandırmanın fonetik özelliklerine göre ne de tarafımızdan yapılan eklemelere göre Altay, Teleüt, Çernevih Türkleri, Korş'un ve Radloff'un Doğu grubu'nun (bizce kuzeybatı) içinde yer alamaz. Korş, bu diyalektlerden bazılarını Kuzey grubu'na bazılarını ise Karmaşık grubu'nun alt gruplarına dâhil etmiştir.

Korş'un Kuzey grubu'nda yer alan diyalektler, yukarıda adı geçen diyalektler dışında, Radloff'un Batı grubu ile denktir. Tarafımızdan belirlenen dil özellikleri, Güneybatı grubu'nu zenginleştirmekte, Kuzeybatı grubu'ndaki diyalektleri ise azaltmaktadır. Tarafımızdan yapılan sınıflandırmada, Korş'un Kuzey grubu'nda ve Radloffun Batı grubu'nda yer alan Altay ve Teleüt diyalektlerini, her iki akademisyenin terminolojisini kullanarak Kuzeybatı grubu adlandırmasını teklif etmekteyiz.

Bu grup, bir taraftan "y" (yot) grubunun diyalektleri (Güneybatı grubu gibi), diğer taraftan "bol-" grubunun diyalektlerini (Kuzeydoğu grubu gibi) ve aynı zamanda "u" (tau "dağ") ayırt edici özelliklerinden dolayı "tau" diyalekti olarak da adlandırılabilir. Bu grupta Altay, Teleüt, Kuman, KaraKırgız, Kumuk, Karaçay, Balkar, Tobol Tatarları, Baraba, Rusya'nın merkezinde bulunan Tatarlar, Meşerler, Başkurtlar, Kırım Tatarları (güney kıyıları hariç), Karaimler (Osmanlılaşmış olanlar hariç), Nogaylar ve Kırgız Kazakları gibi modern şiveler yer alır.

Kuzeybat grubu'nun dillerini ve şivelerini konuşan Türk halklarının yerleşim yerleri Altay bölgesi ile başlar, Batı Sibirya'dan geçer, içine Bozkır bölgesini alır, Tanrı Dağlarının batı bölgesinin bir bölümünü ve Pamir Dağlarının bir bölümünü, Buhara ve Hive sınırlarını, Ural sinırlarını, Volga bölgesini, Oka havzasını, Kuzey Kafkasya ve ona bağlı bozkırları kapsar ve Kırım'da sonlanır. Bunun

13 G. Nemet, Türk dilleri için iki grup oluşturmuştur: 1) Türkçede "s" grubu ve 2) Türkçede "yot" grubu. Yakutçayı ve Çuvaş dillerini "s" grubuna, kelime başında y $>\mathrm{s}$ değişmi barındıran dilleri ise ikinci gruba dâhil eder. Bkz. Türkische Grammatik, 1917, s. 7. Yakutça ve Çuvaş dillerinin arasında bazı ortak noktalar olmasına rağmen şimdilik bu iki dili aynı gruba almak bizce doğru değil. Çuvaş dili hakkındaki bilgiler için makalenin devamına bakınız.

14 V. V. Radloff, "Bericht über die Ausgabe des Sprachmaterials des Codex Cumanicus", makalesinde Kuzeydoğu grubu için aynı teklifte bulunmuştur. Melages Asiatiques, 9(2), s. 89.

15 Bkz. S. K. Patkanov'un "Sibirya nüfusunun asiret bilesimini, yabancıların dilini ve klanlarını gösteren istatistiksel veriler" makalesinde, Radloff un sınıflandırmasına Sibirya'da yaşayan Türkler ile ilgili bazı eklemeler ve düzeltmeler verilmiştir. (s. 55). Bu konu ile ilgili tarafımızdan yapılan çalışma Rusya Bilimler Akademisine sunulacaktır.

Adres $\mid$ Address

RumeliDE Dil ve Edebiyat Araşttrmaları Dergisi $\quad$ RumeliDE Journal of Language and Literature Studies Osmanağa Mahallesi, Mürver Çiçeği Sokak, No:14/8 Osmanağa Mahallesi, Mürver Çiçeği Sokak, No:14/8

Kadıköy - İSTANBUL / TÜRKIYE 34714 Kadıköy - ISTANBUL / TURKEY 34714 e-posta: editor@rumelide.com

e-mail: editor@rumelide.com

tel: +90 505 7958124, +90 216773 o 616 phone: +90 505 7958124, +90 2167730616 
dışında Litvanya'daki küçük adalarda yer alan Karaim kolonilerinin (Troki, Lutsk, Galiç) yerleşim yerleri mevcuttur.

Kuzeybatı grubu'nun dillerini ve şivelerini konuşan modern Türk halklarının kökeni Eski Kıpçak (diğer bir deyişle Polovets veya Kuman) halklarına dayanmaktadır. Böylece bu grup Kıpçakça olarak adlandırılabilir. ${ }^{16}$ Kıpçak diline gelince, şunları söyleyebiliriz:

1. Korş tarafından Kumanca olarak adlandırılmıştır.

2. Kıpçak dilini Doğu grubu’na (bizce Kuzeydoğu grubu) dâhil etmiştir.

\section{Kıpçak dili tarafımızdan Bang'ın sonuçlarına bakmaksızın¹7}

Radloff'un izlerini takip ederek Doğu grubu'ndan çıkarılmış ve Kuzeybatı grubu'na dâhil edilmiştir. Ayrıca, Kıpçak dili hakkında, elimizde olan metinlerden yola çıkarak aynı zamanda şunları söyleyebiliriz, bu dil hem tau diyalektinin hem tag diyalektinin izlerini taşımaktadır.

Diğer gruplar ile karşılaştırdığımızda Kuzeybatı grubu'nun içerdiği dil ve şiveler sayıca fazla olduğundan dolayı daha çok alt grup ayrımına ihtiyaç duyar. Bu gruptaki şiveler arasında yakınlık vardır. Bir taraftan Altayca, Teleütçe, Kara-Kırgızca (tuu-too şivesi) arasında, diğer bir taraftan Kumukca, Karaçayca, Balkarca, Karaim ${ }^{18}$ ve Tatarca arasında, bununla birlikte bir de Kırgız-Kazak ve Nogayça arasında yakınlık mevcuttur. Bize göre Kırgız-Kazak ve Nogayca Moğol sonrası grup; Altayca, Teleütçe, Kara-Kırgızca, Kumukça, Karaçayca, Balkarca, Karaimce Moğol öncesi grup olarak adlandırmalıdır.

\section{VII}

Eğer Kıpçak (Kuman) dili tau diyalekti içinde, yani Kuzeybatı grubu'nda yer alacaksa o zaman tag diyalekti ne Kuzeydoğu grubu'na ne de Güneybatı grubu'na dâhil edilebilir. Çünkü bu gruba ait en önemli dil özelliklerinden "adak, atak, azak" kelimeleri, Kıpçakça "ayak" şeklinde, "kalgan” kelimesi de "kalan” şeklinde geçmektedir. Tarafımızca yapılan sınıfladırmada, Korş’un Doğu grubu'ndan (bizce Kuzeydoğu grubu) çıkarılan Çağatay dili, genel olarak tespit ettiğimiz dil özelliklerinden dolayı ne Güneybatı grubu'na ne de Kuzeybatı grubu'na dâhil edilebilir.

Yine Türk dillerine ve şivelerine ait dördüncü bir grup bulunmaktadır. Bu grup "y" özelliğinden dolayı Kuzeybatı ve Güneydoğu gruplarına bağlı, "bol-/ol-" ve "kalgan-kalan” özelliğinden dolayı Kuzeydoğu ve Kuzeybatı gruplarına bağlı, "tag-tay" özeliğinden dolayı ise Kuzeydoğu ve Güneybatı gruplarına bağlıdır. Bu grup ${ }^{19}$ başka bir deyişle, diğer üç grubun arasında bulunmaktadır. Söz konusu grup tarafımızdan yapılan bazı ilaveler ile Korş’un Karmaşık grubu ve Radloffun Orta-Asya grubu ile eşleşmektedir.

V. V. Radloff, "Bericht über die Ausgabe des Sprachmaterials des Codex Cumanicus", makalesinde de aynı teklifte bulunmuştur. Melages Asiatiques, 9(2), s. 89; Berezin, Recherches sur les Dialectes Musulmans. I. Systeme des Dialectes Turcs'de "Kıpçak grubu" şeklinde adlandırmıștır. (s. 27)

17 W. Bang, I. Marquart, "Osttürkische Dialektsudien", Abhandlungen der K. Gesellschaft der Wissenschaften zu Göttingen. Phil.-hist. Klasse. Neue Folge, 13(1), Berlin, 1921; V. V. Bartold tarafından gözden geçirilmişs şekli: 7. kitapta Rus Tarihi Dergisi, 1921, s. 138.

18 Bkz. J. Grzegorzewski, Ein Türk-Tatarischer Dialekt in Galizien, Wien 1903; a. mlf. "Caraimica. Język Łach-Karaitów", Rocznik Oryentalistyczny, 1/2, s. 252-296.

19 Berezin bu grubu "Çağatay veya doğu" grubu şeklinde adlandırmıştır. (s. 26) Bu gruba ait diller Batı Avrupa'da "Doğu Türkçesi” şeklinde adlandırılır.

RumeliDE Dil ve Edebiyat Araștırmaları Dergisi Osmanağa Mahallesi, Mürver Ciçeği Sokak, No:14/8 Kadıköy - ISTANBUL / TÜRKIYE 34714 e-posta: editor@rumelide.com tel: $+905057958124,+902167730616$
Address

RumeliDE Journal of Language and Literature Studies

Osmanağa Mahallesi, Mürver Çiçeği Sokak, No:14/8

Kadıköy - ISTANBUL / TURKEY 34714

e-mail: editor@rumelide.com,

phone: +90 505 7958124, +90 2167730616 
Bu grubun dil özelliklerini daha iyi ayırt edebilmek için, aynı zamanda tag diyalekti’nin Kıpçak dilinin içinde, yani Tarançin şivesinin yanında yer alamayacağını gösterebilmek maksadıyla Korş’un fonetik özelliklerini çoğaltacağız. Böylece kelime sonunda $g>y$ ünsüzünün değişimi (tag-tay), çok heceli kelimelerde "g” ünsüzünün düşmesi (kalgan-kalan) özellikleri dışında, "g”"nin bir özelliği daha tespit edilmiştir ki bu özellik, kelime sonunda "g”"nin kalın ünlülerle kullanılmasıdır. Tabii ki bu özellik, Korş’un tespit ettiği "g”"nin diğer iki özelliğinden farklıdır. Biz "sarıg-sarı", "atlıg-atlı" gibi kelimelerdeki “-1g/-ig” şekillerinden bahsediyoruz. ${ }^{20}$ Kuzeydoğu grubu'nda, "g” ünsüzünün "Ig” şeklindeki kullanımına devam edilmektedir. Ancak"g” ünsüzü Kuzeybatı ve Güneybatı gruplarında kullanımdan düşmüştür. Tarafımızdan oluşturulan grupta "g” ünsüzü ya korunmakta ya da g>k değişimine uğramaktadır: "sarıg>sarık", "serig>serik", "atlık" gibi. Kıpçak dilinin tag ve tay diyalektleri dil özelliğinden dolayı Çağatay diliyle aynı grupta olmamalıdır. Çağatay diyalekti, Radloffun sinıflandırmasında Orta Asya grubu'nda; V. Bang'ın sinıflandırmasinda ise Doğu grubu'nda yer almaktadır.

Böylece bizim dördüncü grubumuzda tartışmasız şu diller yer alacaktır: Çağatay dili, Çin'deki bütün Türk şiveleri veya "Sardunya” şivesi adıyla anılan Doğu Türkistan’ın şiveleri (Sarıg-Uygur ve Salar şiveleri dışında), Batı Türkistan'ın "Sardunya” şiveleri (Hive-Sart şivesi dışında) ve Fergana, Taşkent ve Semerkant bölgelerinin Özbek şiveleri yer almaktadır. Aynı zamanda, hakkında bazı bilgilere sahip olduğumuz Buhara şiveleri de bulunmaktadır.

Çulım şivesi, Çernevoy bölgesinde bulunan Abin ve Tomsk'ta ${ }^{21}$ tespit ettiğimiz dil özelliklerinden dolayı Kuzeydoğu grubu içinde dördüncü grubun ortasında "y" şivesinde bulunmalı.

Terminolojinin uyumlu olması bakımından söz konusu grubu dilin ana özelliğinden dolayı Güneydoğu grubu olarak adlandırıyoruz. Grubun ana özelliğinden dolayı taghk diyalekti’ni, dil kökeni bakımından ki bu dilin kökeni hakkında herhangi bir bilgi bulunmamaktadır (belki Karluk?), Çağatayca olarak adlandıryoruz. Sonra onu iki alt gruba ayırıyoruz:

1) Çağatayca alt grubu,

2) Çulım, Abin ve Çernevoy şivesi.

Güneydoğu grubu'nun varlığını, daha sonra onun iki farklı gruba ayırılacağını tahmin ederek şimdilik kabul ediyoruz.

Çağatayca grubu'nda mevcut olan diller ve şivelerini konuşan modern Türk nüfusu, Türkistan'in doğusu ve batısında (Hive hariç)22, Trans-Hazar (Türkmen) bölgesinde (Avgan Özbeklerinin şiveleri tarafından bilinmiyor) ve kısmen Tomsk eyaletinde yaşamaktadır.

\section{VIII}

Modern Harezm Cumhuriyetinin (Eski Hive Hanlığı) Hive-Özbek ve Hive-Sart şiveleri ve Kipçak dilinin şivelerinde tespit edilen "tag” çeşitliliği ve özelikleri bizi Radloff un sınıflandırmasında tek bir

20 Bkz. N. F. Катанов, “Опыт исследования урянхайского языка с указанием главнейших родственных отношений его к другим языкам тюркского корня”, çalışmasında s. 88-91, 189-192 ve 3. ile 4. numaralı şema.

21 Bkz. Malov’un, 1909-1911 yılların arasında Doğu ve Orta Asya Araştırmaları Komitesi adına Batı ve Orta Çin'de yaşayan Sarı Uygur, Salar, Lobnor kıyısı Türkleri hakkında yaptı̆̆ çalışmalar.

22 Bkz. Hiveli Abdülgazi Han (17. yy)'ın şiirleri. Şiirler Çağatayca değil, Özbek ile Çağatayca karışımı.

Adres Address

RumeliDE Dil ve Edebiyat Araştırmaları Dergisi $\quad$ RumeliDE Journal of Language and Literature Studies Osmanağa Mahallesi, Mürver Çiçeği Sokak, No:14/8 Osmanağa Mahallesi, Mürver Çiçeği Sokak, No:14/8

Kadıköy - ISTANBUL / TÜRKIYE 34714 Kadıköy - ISTANBUL / TURKEY 34714 e-posta: editor@rumelide.com e-mail: editor@rumelide.com,

tel: +90 505 7958124, +90 2167730616 phone: +90 505 7958124, +90 2167730616 
grupta yer alan Orta Asya grubu'nu iki gruba ayırmaya teşvik etmektedir. Böylece bu grupta az önce incelediğimiz grup, dördüncü grup ve az sonra inceleyeceğimiz beşinci grup yer alacaktır.

Beşinci grubun dil özellikleri ile dördüncü grubun dil özelikleri arasındaki fark, şu özelliklere göre ayrılır: "lg”/“lk” özelliğinden dolayı beşinci grup, dördüncü grup gibi Kuzeydoğu grubuna değil, Kuzeybatı ve Güneybatı gruplarına yaklaşmaktadır. Bunun dışında, Hive-Özbek ve Hive-Sart şiveleri, özellikle Güneybatı grubu'nun önemli bazı dil özelliklerini taşımaktadır. Bu durum Hive Sartlarının ve Özbeklerin Türkmenler ile olan komşuluklarıyla açlklanabilir.

Beşinci grup için hem halk olarak hem dünya ülkelerinin arasındaki konumundan hem de dilin fonetik özelliklerinden dolayı, özel bir adlandırma bulmak zordur. Biz, şu adlandırmalar üzerine durmaktayız: Orta grubu, Kıpçak-Türkmen grubu veya Taglı grubu.

\section{IX}

Yakut dilini hiç çekinmeden Kuzeydoğu grubu'nda (t alt grubu) değerlendirseydik, işte o zaman Çuvaş dili için ayrı ve yeni bir grubu, yani altıncı grubu oluşturabilirdik. Böylece sınıflandırmamıza yeni bir fonetik özellik daha ekleyebilirdik. Çuvaş dilinin dört özelliğinden birincisini alıp diğer Türk dilleri ile karşılaştırdıktan sonra Moğol dil ailesi ile aynı özelikler taşıdığını görmekteyiz.

$\mathrm{Bu}$ özelliğinden dolayı bütün Türk dilleri ve diyalektlerinin iki eşit olmayan gruba ayırıldığını görmekteyiz: "z" (tokuz) ve "r" (tahar "dokuz") dilleri. Birinci grup daha önce işlediğimiz bütün beş grubu kapsayacaktır. İkinci grupta Çuvaş dili ve Çuvaşçanın eski dili, yani Bulgarca yer alacaktır. ${ }^{23} \mathrm{Bu}$ grubu, biz altıncı grup, yani Bulgar dili grubu olarak adlandırılmasını teklif ediyoruz. Bulgar dili grubu'ndaki "r" ünsüzünün özelliği ile Kuzeydoğu grubu'nun alt grubundaki "z" ünsüzünün özelliği ve diğer gruplardaki "y” ünsüzünün özelliği (ura-azak-ayak) birbiriyle eşleşmektedir. Böylece bu iki özelliğinden dolayı Bulgar dili grubu diğer beş gruptan görünür bir şekilde ayrılmaktadır. Başka dil özelliklerinden dolayı Bulgar dili grubu diğer gruplarla yakınlaşmaktadır: "ol-bol" dil özelliğinden dolayı "bol-“(pul) dillerine, "tag-tau" dil özelliğinden dolayı "tau” (tu” "dağ”) dillerine, "1g-ı" dil özelliğinden dolayı "ı" dillerine, "kalgan-kalan” özelliğinden dolayı "kalan” dillerine yakınlaşmaktadır.

\section{$\mathbf{X}$}

Radloff un sınıflandırması, bizim sınıflandırmamız gibi sadece fonetik özelliklere dayanmaktadır. Korş tarafından belirlenen "şimdiki zaman" morfolojik özelliği, bize göre yeterince açık ve geliştirilmiş değildir. Türk dilleri sınıfladırmasının devamında, fonetik özelliklerine göre iki özellik daha eklenebilir:

1. Kelime başında "y-c" uyumu,

2. Birinci heceden sonra "o-a” ve "ö-e" ünlüleri ile dudak ünsüzlerin uyumu. 
Türk dillerin en basit sınıflandırma şeması şu şekilde olabilir:

\begin{tabular}{|c|c|c|c|c|c|c|c|}
\hline 1 & Tahar grubu & & \multicolumn{3}{|c|}{ Tokuz (dokuz) grubu } & & \\
\hline 2 & Ura grubu & Adak grubu & \multicolumn{3}{|l|}{ Ayak grubu } & & \\
\hline 3 & \multicolumn{5}{|c|}{ Bol (pol, pul, bul) grubu } & Ol grub & \\
\hline 4 & Tau (tu) grubu & Tag grubu & \multicolumn{3}{|l|}{ Tay grubu } & \multicolumn{2}{|c|}{ Tag (dag) grubu } \\
\hline 5 & I grubu & Ig grubu & \multicolumn{3}{|l|}{ I grubu } & $\begin{array}{l}\text { Ik(1g) } \\
\text { grubu }\end{array}$ & $\begin{array}{l}\text { I } \\
\text { grubu }\end{array}$ \\
\hline 6 & Kalan (yulna) & \multicolumn{4}{|l|}{ Kalgan grubu } & \multicolumn{2}{|c|}{ Kalan grubu } \\
\hline & $\begin{array}{l}\text { I. r grubu } \\
\text { Bulgarca }\end{array}$ & $\begin{array}{l}\text { II. d grubu } \\
\text { Uygurca } \\
\text { [kuzeydoğu] }\end{array}$ & $\begin{array}{l}\text { III. grubu } \\
\text { Tau } \\
\text { Kıpçakça } \\
\text { [kuzeybatı] }\end{array}$ & $\begin{array}{l}\text { IV. grubu } \\
\text { Tag-lık } \\
\text { Çağatay } \\
\text { [guneydoğu] }\end{array}$ & $\begin{array}{l}\text { V. grubu } \\
\text { Tag-lı } \\
\text { Kıpçak- } \\
\text { Türkmence } \\
\text { (merkez) }\end{array}$ & $\begin{array}{l}\text { VI. grub } \\
\text { Ol } \\
\text { Türkme } \\
\text { [güneyb }\end{array}$ & \\
\hline
\end{tabular}

